\title{
Kinetics, distribution, and sites of destruction of indium-111 oxine labelled red cells in haemolytic anaemia
}

\author{
A DU P HEYNS, MG LÖTTER, HF KOTZÈ, P WESSELS, H PIETERS, PN BADENHORST \\ From the Blood Platelet Research Unit of the University of the Orange Free State and the South African \\ Medical Research Council and the Department of Biophysics, Bloemfontein 9300, Republic of South Africa
}

SUMMARY The survival of red cells labelled with indium-111 oxine in the circulation was determined. In vivo distribution at equilibrium and sites of deposition at the $T_{50} I n-$ that is, the half life of labelled red cells - were quantitated with a scintillation camera and computer assisted image analysis. Although the rate of elution. of "1'In from the red cells was higher than that of chromium-51-disodium chromate, estimates of $T_{50}$ In and $T_{50} C r$ corresponded reasonably well and were shortened in haemolytic anaemia. In normal subjects red cells were sequestered mainly in the liver and spleen. In five patients with different types of haemolytic anaemia two distinct patterns of red cell sequestration could be recognised: mainly splenic sequestration, and destruction of red cells in the liver, spleen, and the bone marrow. These patterns were expected for the particular disease studied.

The determination of the life span and the sites of sequestration of red cells is often a useful adjunct in the investigation of a patient with haemolytic anaemia. The recommended method for these studies is labelling of a random cell population with chromium-51-disodium chromate $\left({ }^{51} \mathrm{Cr}\right) .{ }^{12}$ Although the $320 \mathrm{keV}$ photons of ${ }^{51} \mathrm{Cr}$ is adequate for in vitro counting and permits external monitoring of organ radioactivity, this radionuclide has several disadvantages. The elution rate from red cells is significant and may be $5 \%$ per day in patients. ${ }^{3}$ The $10 \%$ photon yield of ${ }^{51} \mathrm{Cr}$ is too low for imaging the in vivo isotope distribution and determining organ radioactivity with external detectors is unreliable. ${ }^{23}$

Indium-111 oxine ("''In) is an alternative blood cell label. ${ }^{4} "$ 'In has $90 \%$ and $94 \% \gamma$ emissions per disintegration for the 172 and $247 \mathrm{keV}$ photon energies, respectively, which facilitates imaging of the in vivo distribution of isotope labelled cells. Labelling efficiency of red cells is high (greater than $90 \%$ ) and $80 \%$ of the ${ }^{1 "}$ In is bound to haemoglobin and $20 \%$ to membrane..$^{5}$ Although the relatively high binding to red cell membrane makes considerable elution of radionuclide from the erythrocyte likely, it was nevertheless thought worthwhile to evaluate the clinical usefulness of estimates of life

Accepted for publication 9 October 1984 span and quantification of sites of destruction of "'In labelled erythrocytes. The patients selected were considered likely to illustrate different patterns of reticuloendothelial system sequestration of red cells. Although several technical and interpretative problems emerged, the advantages of measuring accurately the in vivo distribution of labelled red cells may make the technique useful in clinical practice.

\section{Patients and methods}

PATIENTS AND CONTROLS

The relevant details of the five patients are given in Table 1. All were in a haematological steady state as reflected by a constant haemoglobin concentration and reticulocyte count during the investigation. Five healthy young adults, one man and four women, acted as controls.

\section{LABELLING OF RED CELLS}

Blood $(17.5 \mathrm{ml})$ was collected into a syringe containing $2.5 \mathrm{ml}$ of acid citrate dextrose. Three millititres of a $6 \%$ solution of hydroxyethyl starch was added and the syringe left upright for $1 \mathrm{~h}$. The buffy coat and plasma were removed. The red cells were washed three times with $10 \mathrm{ml}$ normal saline and centrifuged at $180 \mathrm{~g}$ for $10 \mathrm{~min}$. The erythrocytes 
Kinetics, distribution, and destruction of indium-111 oxine labelled red cells in haemolytic anaemia

Table 1 Clinical details and red cell survival and scintigraphic data

\begin{tabular}{|c|c|c|c|c|c|c|c|c|}
\hline \multirow[t]{2}{*}{ Patient } & \multirow{2}{*}{$\begin{array}{l}\text { Sex } \\
\text { Age }\end{array}$} & \multirow[t]{2}{*}{ Diagnosis } & \multirow{2}{*}{$\begin{array}{l}\text { Haemoglobin } \\
\text { concentration } \\
\text { (g/dl) }\end{array}$} & \multirow{2}{*}{$\begin{array}{l}\text { Reticulocyte } \\
\text { count } \\
\left(\times 10^{\prime \prime} / l\right)\end{array}$} & \multirow{2}{*}{$\begin{array}{l}\text { "'In } \\
\text { administered } \\
(M B q)\end{array}$} & \multicolumn{2}{|c|}{ Red cell survival data } & \multirow{2}{*}{$\begin{array}{l}\text { Scintigraphy: pattern of } \\
\text { sequestration }\end{array}$} \\
\hline & & & & & & $\begin{array}{l}{ }_{\text {S1 }} \mathrm{Cr} \mathrm{T}_{\mathrm{so}} \mathrm{Cr} \\
\text { (days) }\end{array}$ & $\operatorname{lin}_{\text {(days) }} T_{\text {so }} \ln$ & \\
\hline $\begin{array}{l}\overline{1} \\
2\end{array}$ & $\begin{array}{l}\text { Male } 60 \\
\text { Male } 65\end{array}$ & $\begin{array}{l}\text { Congenital spherocytosis } \\
\text { Idiopathic autoimmune } \\
\text { haemolytic anaemia: IgG } \\
\text { antibody with poly-Rh } \\
\text { specificity }\end{array}$ & $\begin{array}{r}13 \cdot 2 \\
8 \cdot 5\end{array}$ & $\begin{array}{l}420 \\
696\end{array}$ & $\begin{array}{l}14 \cdot 9 \\
12 \cdot 2\end{array}$ & $\begin{array}{r}11 \cdot 5 \\
3 \cdot 0\end{array}$ & $\begin{array}{l}7 \cdot 3 \\
2 \cdot 5\end{array}$ & $\begin{array}{l}\text { Mainly splenic } \\
\text { Mainly splenic (Fig. 1) }\end{array}$ \\
\hline $\begin{array}{l}3 \\
4\end{array}$ & $\begin{array}{l}\text { Male } 17 \\
\text { Male } 62\end{array}$ & $\begin{array}{l}\text { Congenital stomatocytosis } \\
\text { Cold agglutinin disease; IgM } \\
\text { antibody with anti-I specificity }\end{array}$ & $\begin{array}{r}9 \cdot 0 \\
6 \cdot 7\end{array}$ & $\begin{array}{l}580 \\
657\end{array}$ & $\begin{array}{l}12 \cdot 2 \\
14 \cdot 7\end{array}$ & $\begin{array}{r}14 \cdot 9 \\
7 \cdot 8\end{array}$ & $\begin{array}{l}7 \cdot 2 \\
5 \cdot 1\end{array}$ & $\begin{array}{l}\text { Liver; spleen; bone marrow } \\
\text { Liver; spleen; bone marrow } \\
\text { (Fig. 2) }\end{array}$ \\
\hline 5 & Male 52 & $\begin{array}{l}\text { Haemolytic anaemia of } \\
\text { undetermined cause; red cells } \\
\text { coated with complement }\end{array}$ & $9 \cdot 5$ & 396 & $14 \cdot 1$ & $7 \cdot 9$ & $5 \cdot 3$ & $\begin{array}{l}\text { Mainly in liver; also spleen } \\
\text { and bone marrow }\end{array}$ \\
\hline \multicolumn{2}{|c|}{$\begin{array}{l}\text { Normal subjects } \\
\text { Range or mean (SD) }\end{array}$} & & $14 \cdot 0-16 \cdot 2$ & $10-100$ & $15.0(0.5)$ & $28.7(7 \cdot 5)$ & $13 \cdot 2(3.0)$ & $\begin{array}{l}\text { Mainly in liver and spleen; } \\
\text { bone marrow not visualised }\end{array}$ \\
\hline
\end{tabular}

were suspended in $10 \mathrm{ml}$ of saline, approximately $18.6 \mathrm{MBq}(500 \mu \mathrm{Ci}){ }^{11}$ In-oxine (Radiochemical Centre, Amersham) was added, and the cells were incubated for $5 \mathrm{~min}$ at $37^{\circ} \mathrm{C}$. The erythrocytes were washed three times in saline and resuspended in 5 $\mathrm{ml}$ of autologous platelet poor plasma for reinjection.

Labelling of red cells with ${ }^{51} \mathrm{Cr}$ was performed as recommended by the ICSH.'

\section{RED CELL LIFE SPAN}

This is expressed as the $\mathrm{T}_{50} \mathrm{Cr}$ and $\mathrm{T}_{50} \mathrm{In}$-that is, the time taken for half of the radioactivity to leave the circulation.

The rate of elution of "'In from red cells was estimated from the mathematical model, assuming that all circulating red cells have the same potential life span and are subject to random destruction at a constant rate.'

\section{IMAGING AND QUANTIFICATION OF}

DISTRIBUTION OF '' IN LABELLED RED CELLS

Image acquisition and quantification of "'In labelled red cell distribution were performed with a scintillation camera interfaced with a computer assisted image processing system using the method previously described for platelet studies. ${ }^{67}$

Briefly, anterior and posterior whole body "'I In radioactivity was measured $30 \mathrm{~min}$ after reinjection of labelled cells and daily for nine days. Regions of interest were selected by computer analysis, and the radioactivities of the spleen and liver were determined. The region of interest "'In radioactivity was corrected for attenuation by the geometrical mean method-that is, calculating the square root of the product of the anterior and posterior measurements. Region of interest radioactivity is expressed as a percentage of the whole body geometrical mean count. The relation between changes in whole body and region of interest ${ }^{11}$ In radioactivity with time was determined by least square regression analysis of data. Radioactivity of regions of interest at equilibrium and at the red cell $\mathrm{T}_{\mathbf{s o}_{0}}$ In was derived by extrapolation of the regression line.

\section{STATISTICAL METHODS}

Student's $t$ test was used to test for differences between means.

\section{Results}

RED CELL SURVIVAL

The relevant clinical, laboratory, and red cell survival data are given in Table 1.

Red cell half life was shortened in all patients; results of $\mathrm{T}_{s 0} \mathrm{Cr}$ and $\mathrm{T}_{\text {so }}$ In corresponded reasonably well in some patients, but in others there were striking differences.

In the normal subjects the $T_{50}$ In of $13.2 \pm 3.0$ days was considerably shorter than that of ${ }^{51} \mathrm{Cr}(28.7$ \pm 7.5 days). The elution rate of "'In from red cells in the normal subjects was high and estimated to be $7.9 \%$ per day.

\section{SITES OF DESTRUCTION OF "'IN LABELLED RED}

CELLS

The "'In radioactivity of the whole body, spleen, and liver at equilibrium and at the $T_{50}$ In are given in Table 2. The organ distribution at $T_{50}$ In is illustrated in the scintigraphs of Figs. 1 and 2 and described in Table 1.

\section{CONTROLS}

Whole body radioactivity decreased significantly with time $(\mathrm{p}<0.001)$ and was variable. Splenic radioactivity increased by about half at $T_{50}$ In whereas that of the liver doubled.

PATIENTS

Whole body radioactivity also decreased 
Table 2 Organ and whole body "'In radioactivity at equilibrium and at $T_{\text {so }}$ In

\begin{tabular}{|c|c|c|c|c|c|c|c|c|}
\hline & \multicolumn{4}{|c|}{ Equilibrium } & \multicolumn{4}{|l|}{$T_{s o l} \ln$} \\
\hline & Spleen & Liver & $\begin{array}{l}\text { Spleen:liver } \\
\text { ratio }\end{array}$ & Whole body & Spleen & Liver & $\begin{array}{l}\text { Spleen:liver } \\
\text { ratio }\end{array}$ & Whole body \\
\hline $\begin{array}{l}\text { Patients } \\
\quad 1 \\
2 \\
3 \\
4 \\
5 \\
\text { Controls }\end{array}$ & $\begin{array}{l}17 \cdot 9 \\
14 \cdot 1 \\
10 \cdot 4 \\
12 \cdot 2 \\
7 \cdot 7\end{array}$ & $\begin{array}{r}8.0 \\
9.1 \\
10.4 \\
7.8 \\
30.0\end{array}$ & $\begin{array}{l}2.2 \\
1.6 \\
1.0 \\
1.6 \\
0.3\end{array}$ & $\begin{array}{l}100 \\
100 \\
100 \\
100 \\
100\end{array}$ & $\begin{array}{r}23.7 \\
36 \cdot 8 \\
9 \cdot 3 \\
10.5 \\
13.2\end{array}$ & $\begin{array}{l}13 \cdot 8 \\
13.4 \\
18 \cdot 1 \\
14.5 \\
26.4\end{array}$ & $\begin{array}{l}1.7 \\
2.8 \\
0.5 \\
0.7 \\
0.5\end{array}$ & $\begin{array}{c}74.9 \\
92.1 \\
100 \\
92.8 \\
81.5\end{array}$ \\
\hline $\begin{array}{l}\text { Controls } \\
1 \\
2 \\
3 \\
4 \\
5 \\
\text { Mean (1SD) }\end{array}$ & $\begin{array}{l}2.9 \\
3.4 \\
3.0 \\
2.4 \\
2.7 \\
2.9(0.4)\end{array}$ & $\begin{array}{r}9.0 \\
12.7 \\
9.2 \\
11.2 \\
11.6 \\
10.7(1 \cdot 6)\end{array}$ & $\begin{array}{l}0.3 \\
0.3 \\
0.3 \\
0.2 \\
0.2 \\
0.26(0.05)\end{array}$ & $\begin{array}{l}100 \\
100 \\
100 \\
100 \\
100 \\
100(0)\end{array}$ & $\begin{array}{l}1 \cdot 5 \\
6 \cdot 4 \\
5 \cdot 3 \\
4 \cdot 2 \\
6 \cdot 0 \\
4 \cdot 7(2 \cdot 0)\end{array}$ & $\begin{array}{l}24 \cdot 8 \\
29 \cdot 4 \\
24 \cdot 5 \\
31 \cdot 6 \\
20 \cdot 4 \\
26 \cdot 1(4 \cdot 4)\end{array}$ & $\begin{array}{l}0.06 \\
0.2 \\
0.2 \\
0.1 \\
0.3 \\
0.17(0.09)\end{array}$ & $\begin{array}{l}76 \cdot 6 \\
96 \cdot 1 \\
85.2 \\
72.5 \\
79.7 \\
81 \cdot 0(10 \cdot 1)\end{array}$ \\
\hline
\end{tabular}

Organ "'In radioactivity is expressed as a percentage of whole body radioactivity.

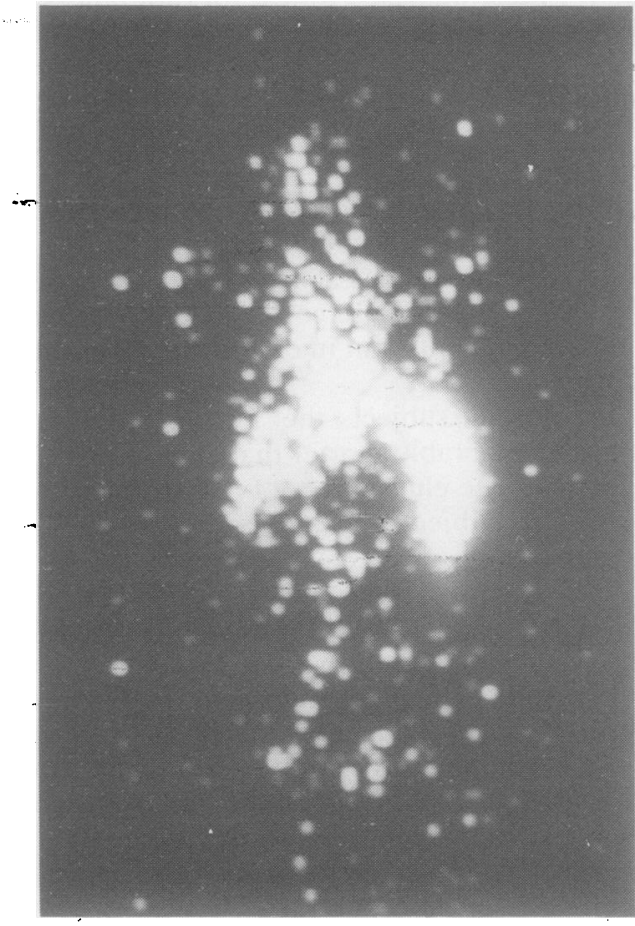

Fig. 1 Anterior scintigraph of the distribution of '1'In radioactivity at the $T_{\text {so }}$ In in a patient with congenital spherocytosis (patient 1). The accumulation of radioactivity especially in the spleen is obvious. Note that the bone marrow is not visualised. The activities in the heart and liver are of about equal intensity.

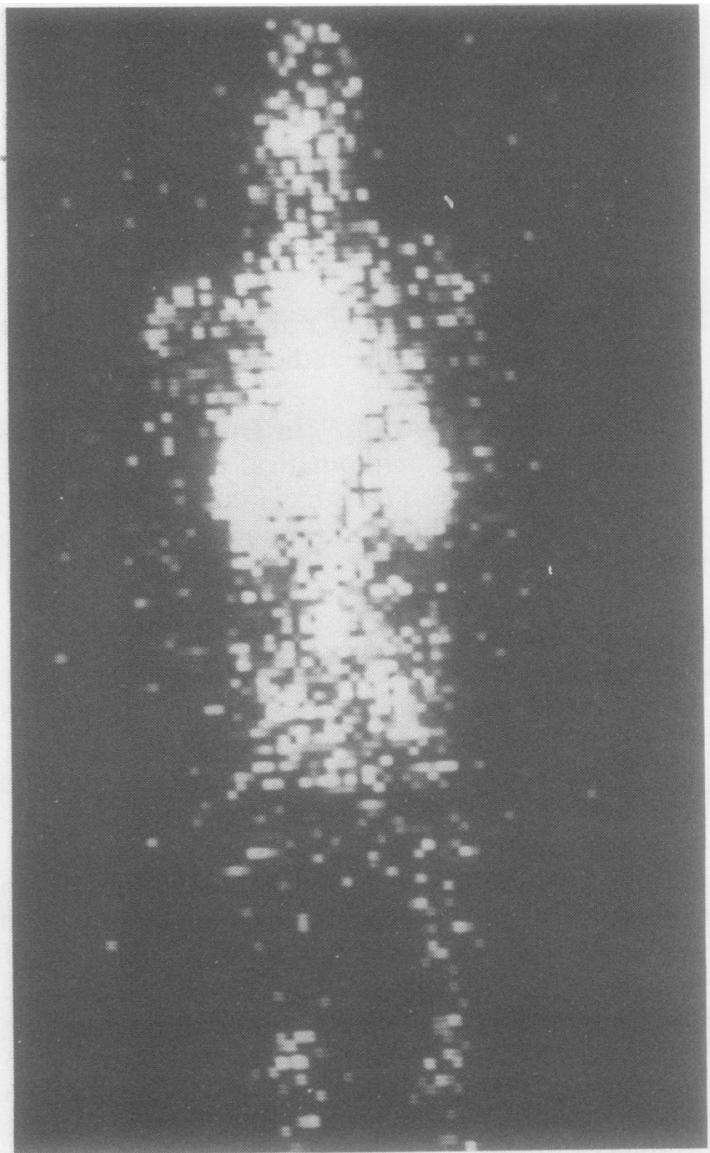

Fig. 2 Anterior scintigraph of the distribution of "'In radioactivity at the $T_{\text {sol }}$ in in a patient with cold agglutinin disease (patient 4). The liver, spleen, and pelvis are clearly seen. 
significantly with time $(\mathrm{p}<0.001)$, was variable, but was of the same magnitude as that of the controls. At equilibrium, the splenic "'In activity was much higher in all the patients than that of the controls ( $p$ $<0.0005$ ), but liver activity was high only in patient 5 . These findings are also reflected by the respective spleen to liver ratios.

Two patterns of red cell destruction could be recognised: considerable cell sequestration in the spleen (patients 1 and 2) and sequestration diffusely in all components of the reticuloendothelial system (patients 3, 4, and 5). These patterns are reflected by the $T_{50}$ In organ radioactivity and the spleen to liver ratios (Table 2) and are illustrated in the scintigraphs (Figs. 1 and 2).

\section{Discussion}

Since "'In has a physical half life of only $2 \cdot 8$ days it cannot replace ${ }^{51} \mathrm{Cr}$ as a radiopharmaceutical for the determination of red cell survival. ${ }^{11}$ In, however, has strikingly superior physical properties and its high gamma emission makes in vivo quantification and scintigraphic visualisation of isotope distribution possible. The new technology of computer assisted imaging also permits accurate selection and delineation of organs and other regions of interest. This methodology has been applied successfully in quantitative studies of platelet kinetics. ${ }^{6-8}$

In normal subjects it appears that the liver and spleen are major sites of destruction of senescent red cells. That radioactivity not in the liver or spleen at the $T_{s 0}$ In may reflect some bone marrow sequestration of red cells, but because of the diffuse distribution of the marrow this could not be quantitated or visualised. At the $T_{50}$ In there are also appreciable numbers of labelled red cells in the circulation and this will obviously contribute to the background radioactivity. The high rate of elution of "'In may also influence the results: injected free ${ }^{11}$ In localises especially in the liver but also in the spleen and the bone marrow. ${ }^{9}$ Also, after uptake of cell bound isotope there is a slow redistribution of ${ }^{11}$ In from the spleen to the liver, presumably as plasma ${ }^{111}$ In. ${ }^{9}$ It is therefore apparent that hepatic ${ }^{11}$ In activity may increase progressively with time and may be falsely high. It also follows that splenic and especially bone marrow ${ }^{11}$ In radioactivity will indeed reflect uptake by these organs of spent or damaged red cells. Obviously, in subjects with normal red cell survival quantification of red cell distribution at the $T_{50}$ In is seriously impaired by the short half life of "'In.

Many of these problems become less pronounced when the red cell survival is shortened. The results in the five patients with haemolytic anaemia were as expected for the specific disease. The splenic sequestration in congenital spherocytosis (patient 1) and IgG antibody mediated autoimmune haemolytic anaemia (patient 2) was clearly reflected by the quantitative data and the scintigraphic images. In this small series it was easy to separate these patients from patients 3,4 , and 5 with a pattern of sequestration of red cells mainly in the liver, but also in the spleen and the bone marrow. This diffuse reticuloendothelial system sequestration pattern was characterised by a moderate increase in the spleen to liver ratio and a scintigraph clearly showing all three organs (Fig. 2).

The methodology of the quantification of in vivo distribution of "In with the geometrical mean method for correction of attenuation has been verified and found to be accurate to within about $6 \% .{ }^{1011}$ The radiation dose to the critical organs is also acceptable for human studies. ${ }^{12} 13$ The elution rate of "In from reticuloendothelial cells is lowthat is, only about $2 \%$ of the initial splenic activity per day. ${ }^{9}$ The measurement of "'In accumulation in the spleen, liver, and bone marrow should reflect mainly uptake of red cells in the organs and not redistribution of isotope.

Several problems should, however, be recognised when interpreting the data. The half life of "'In is short relative to red cell survival time, and this makes estimates of red cell life span inaccurate, especially in normal subjects. The rate and variation of elution of "'In from the red cell are important, especially when red cell survival is normal or only slightly reduced.' The estimated rate of elution (7.9\% per day) of "'In is high compared with the loss of about $1 \%$ of ${ }^{51} \mathrm{Cr}$ per day. ${ }^{1}$ The elution from abnormal cells may also vary.' This high rate of elution of "'In from the red cells is clearly reflected by the short $T_{50} I n$ as compared with the $T_{50} \mathrm{Cr}$ in normal subjects (Table 1). Since $20 \%$ of ${ }^{\prime \prime} 1 \mathrm{In}$ is bound to the red cell membrane, ${ }^{5}$ the pathological processes involved in red cell destruction may also affect the rate of elution.

Despite these reservations the results of the study of red cell kinetics of "'in oxine labelled cells in patients with haemolytic anaemia are promising, and it may be a suitable method of forecasting the response to splenectomy. Quantification of in vivo distribution of "'In labelled red cells is made possible by the application of the modern technology of the scintillation camera and a computer assisted imaging system. The limitations imposed by the high rate of elution of the radionuclide will be overcome if a ligand that binds indium firmly to red cells is found.

This project was supported by the South African 
Medical Research Council and the Central Research Fund of the University of the Orange Free State. The secretarial assistance of Mrs E Herbst is gratefully acknowledged.

\section{References}

' ICSH Panel on Diagnostic Application of Radioisotopes in Haematology. Recommended methods for radioisotope redcell survival studies. Br J Haematol 1971;21:241-50.

${ }^{2}$ ICSH Panel on Diagnostic Application of Radioisotopes in Haematology. Recommended methods for surface counting to determine sites of red-cell destruction. $\mathrm{Br} J$ Haematol 1975;30:249-54.

${ }^{3}$ Pollycove M, Tono M. Studies of the erythron. Semin Nucl Med 1975;5:11-61.

4 Thakur ML, Welch MJ, Joist JH, Coleman RE. Indium-111 labelled platelets: Studies on preparation and evaluation of in vivo and in vitro functions. Thromb Res 1976;9:345-57.

${ }^{5}$ Dewanjee MK, Rao SA. Red cell membrane permeability and metal oxine-haemoglobin transchelation; implications in cell labeling. Journal of Labelled Compounds and Radiopharmaceuticals 1972; XVIII: 278 .

- Heyns A du P, Lötter MG, Badenhorst PN, et al. Kinetics, distribution and sites of destruction of Indium-111-labelled human platelets. Br J Haematol 1980; 44:269-80.

' Heyns A du P, Lötter MG, Badenhorst PN, Pieters H, Nel CJC,
Minnaar PC. Kinetics, and fate of Indium-111-oxine labeled platelets in patients with aortic aneurysms. Arch Surg 1982;117: 1170-4.

${ }^{8}$ Heyns A du P, Lötter MG, Pieters $\mathrm{H}$, et al. A quantitative study of indium-111-oxine platelet kinetics in acute and chronic renal transplant rejection. Clin Nephrol 1982;18:174-82.

' Peters AM, Klonizakis I, Lavender JP, Lewis SM. Elution of In-111 from reticuloendothelial cells. J Clin Pathol 1982;32:507-9.

${ }^{10}$ Van Reenen OR, Lötter MG, Heyns A du P, et al. Quantification of the distribution of In-111-labelled platelets in organs. Eur J Nucl Med 1982;7:80-4.

" Heyns A du P, Lötter MG, Kotzè HF, Pieters H, Wessels P. Quantification of in vivo distribution of platelets labelled with indium-111-oxine. J Nucl Med 1982;23:943-4.

12 Van Reenen OR, Lötter MG, Minnaar PC, Heyns A du P, Badenhorst PN, Pieters $H$. Radiation dose from human platelets labelled with indium-111. Br J Radiol 1980;53:7905.

${ }^{13}$ Robertson JS, Dewanjee MK, Brown ML, Fuster V, Chesebro JH. Distribution and dosimetry of In-111-labelled platelets. Radiology 1981;140:169-76.

Requests for reprints to: Professor A du P Heyns, Blood Platelet Research Unit, Department of Haematology, PO Box 339 (G2), Bloemfontein 9300, Republic of South Africa. 